\title{
Knowledge, attitude and practices of pregnant women regarding anemia, iron rich diet and iron supplements and its impact on their hemoglobin levels
}

\author{
Nivedita K.*, Fatima Shanthini N.
}

Department of Obstetrics \& Gynaecology, Sri Manakula Vinayagar Medical College \& Hospital,Puducherry, India

Received: 09 December 2015

Accepted: 07 January 2016

*Correspondence:

Dr. Nivedita K.,

E-mail: niveog91@yahoo.com

Copyright: (c) the author(s), publisher and licensee Medip Academy. This is an open-access article distributed under the terms of the Creative Commons Attribution Non-Commercial License, which permits unrestricted non-commercial use, distribution, and reproduction in any medium, provided the original work is properly cited.

\section{ABSTRACT}

Background: Anemia in pregnancy has detrimental effects on maternal and child health and prevalence of anemia during pregnancy is alarmingly high, inspite of the implementation of the national nutritional anemia prophylaxis programme which provides iron and folic acid which are the essential nutrients lacking in their diet. The purpose of this study was to assess the knowledge, attitude and practices of pregnant women regarding anemia, Iron rich food and iron supplements and also to assess the impact of these factors and other socio demographic variables on the hemoglobin levels of these vulnerable groups of women.

Methods: This is a cross sectional, descriptive institution based study conducted at Sri Manakula Vinayagar medical college hospital, Puducherry, India. Sample size was calculated using formula for single proportion with 5\% marginal error and $95 \% \mathrm{CI}$ and a non-response rate of $10 \%$ and was found to be 316. Data collection was carried out using a predesigned, self-administered questionnaire in local language in the antenatal clinic at the time of routine antenatal checkup, from pregnant women who consented to participate in the study. At the same sitting, $1 \mathrm{ml}$ of blood was collected for hemoglobin estimation, analyzed and the result was recorded and disclosed to the patient. The data was entered in SPSS and analyzed using descriptive and inferential statistics (Chi square test). A p value of $<0.05$ was considered to be statistically significant.

Results: Assessment of knowledge revealed that only $39.87 \%$ of the participants were aware of and understood the term anemia. $53.8 \%$ of the participants accepted that pregnant women were more vulnerable to anemia and $66.1 \%$ responded correctly that the fetus will be affected by severe anemia. Only $32.6 \%$ gave the correct response that pregnant women should take iron supplementation in spite of taking a healthy diet. Only $44.62 \%$ of the participants were aware of their hemoglobin level in the current pregnancy. Knowledge about food rich in iron was poor among the participants. At least $1 / 5^{\text {th }}$ of the participants have not received educational information regarding anemia from any source. The overall attitude towards antenatal checkup, healthy diet and the benefits of iron supplementation was generally good among the participants $49.36 \%$ of the participants were taking only the usual diet during their pregnancy. $74.36 \%$ claimed to have taken iron supplementation regularly whereas $9.8 \%$ had not taken iron supplementation. On hemoglobin estimation it was found that $62.97 \%$ of the participants were anemic taking 11 grams as the cut off for anemia. The only significant determinants of hemoglobin levels were regular intake of iron supplements ( $p$ value 0.006 ) and timing of iron consumption ( $p$ value 0.0262 ).

Conclusions: The present study indicated the lack of knowledge regarding anemia, iron rich foods and the importance of iron supplementation during pregnancy. Targeted estimation of hemoglobin levels in adolescent girls and women in reproductive age group, intensive counseling and motivation of pregnant women to consume Iron and folic acid and ensuring adequate supply to them, intensive de-worming, provision of toilet facilities to all households would help in reducing the incidence of anemia in pregnant women.

Keywords: Anemia, Iron rich diet, Iron supplements, Hemoglobin levels, Pregnant women 


\section{INTRODUCTION}

Maternal mortality is one of the important indicators of quality of health services in a country and anemia during pregnancy is one of the important causes for maternal mortality. Anemia is a very common health hazard and as per the NFHS-3 survey the incidence of anemia in Indian women in the age group of 15-49 years is 55.3\%. ${ }^{1}$ The prevalence of anemia in pregnant women who are the most vulnerable group of the society was $58.7 \%$. $^{1}$ Another data showed that $87 \%$ of pregnant women in India were anemic and anemia contributed to 22,000 maternal deaths. ${ }^{2}$ The national nutritional anemia prophylaxis programme was introduced and being implemented since 1970 but the desired impact was not obtained due to various reasons. The incidence of anemia in ever married women who constitute the vulnerable group has in fact raised from $51.8 \%$ in the NFHS 2 survey to $56.2 \%$ in the NFHS 3 survey. ${ }^{1}$ It was found in the NFHS 3 survey, that even though the Iron and folic acid coverage to pregnant women was good, only $23 \%$ reported to have consumed Iron and folic acid tablets for at least 90 days during their pregnancy. This negative impact and poor compliance of pregnant women is due to their inadequate knowledge regarding anemia, iron rich food and avoidance of iron supplements due to misconceptions. Negative attitudes towards antenatal visits, importance of a healthy diet, iron and folic acid intake during pregnancy could have a profound influence on their hemoglobin levels.

Variables other than their knowledge, attitude and practices could also influence the hemoglobin states of pregnant women namely socio demographic factors like education, income, parity, exposure to counselling regarding anemia and also toilet facility at home which is related to hook worm infestation.

The purpose of this study was to assess the knowledge, attitude and practices of pregnant women regarding anemia, Iron rich food and iron supplements and also to assess the impact of these factors and other socio demographic variables on the hemoglobin levels of these vulnerable groups of women.

\section{METHODS}

This is a cross sectional, descriptive institution based study conducted at Sri Manakula Vinayagar medical college hospital, Puducherry, India to assess the knowledge, attitude and practices of antenatal women regarding anemia, iron rich food and iron supplementation and also to assess the impact of socio demographic factors, knowledge, attitude and practices on their hemoglobin levels. Institutional ethical committee approval was obtained.

Sample size was calculated using formula for single proportion with 5\% marginal error and 95\% CI and a non-response rate of $10 \%$ and was found to be 316 and a consecutive sampling technique was used to collect data. Data collection was carried out using a predesigned, selfadministered questionnaire in local language in the antenatal clinic at the time of routine antenatal check-up from pregnant women who consented to participate in the study.

The questionnaire had details of socio demographic data and questions to assess knowledge, attitude and practices of these antenatal women regarding anemia, iron rich food and iron supplementation. Knowledge part of the questionnaire had questions regarding their awareness of the term anemia, cause of anemia, complications due to anemia and regarding iron supplementation with a score of 1 for the correct response and a zero score for a incorrect or nil response. Attitude regarding antenatal check-up, blood test during pregnancy and healthy diet was assessed using a 3 point Likert scale. Questionnaire had 4 items on practice which included information on their diet, iron supplementation, timing of consumption of iron and reason for not taking iron. At the same sitting, $1 \mathrm{ml}$ of blood was collected for hemoglobin estimation, analyzed and the result was recorded and disclosed to the patient.

The data was entered in SPSS and analyzed using descriptive and inferential statistics (Chi square test). A $P$ value of $<0.05$ was considered to be statistically significant.

\section{RESULTS}

Among the 316 participants $87.3 \%$ belonged to the age group of 20-29 and $60.12 \%$ were multiparous. Most of them $(88.2 \%)$ were homemakers and $57.9 \%$ were in the third trimester of pregnancy. Majority had completed school education $(63.29 \%)$. It was noted that $25.7 \%$ of the participants did not have toilet facility at home and resorted to open air defecation which is a high risk factor for hookworm infestation and hence anemia (Table 1).

Assessment of knowledge revealed that only $39.87 \%$ of the participants were aware of and understood the term anemia. Awareness regarding the prevalence and complications of anemia was good. $53.8 \%$ of the participants accepted that pregnant women were more vulnerable to anemia and $66.1 \%$ responded correctly that the fetus will be affected by severe anemia. Only $32.6 \%$ gave the correct response that pregnant women should take iron supplementation inspite of taking a healthy diet. Awareness that tea and coffee can act as inhibitors of iron absorption was present in $33.2 \%$ of participants but only $42.08 \%$ of them were aware that consuming iron along with food will reduce side effects. More than $1 / 3^{\text {rd }}$ of the participants were aware that iron tablets were dispensed free of cost in government hospitals. Only $44.62 \%$ of the participants were aware of their hemoglobin level in the current pregnancy (Table 2). 
Inadequate consumption of iron rich diet was cited as the reason for anemia during pregnancy by $81.96 \%$ of the participants. Only $23.1 \%$ of them were aware of the fact that hook worm infestation could lead to anemia (Table 3).

Awareness that green leafy vegetables and dates as good sources of iron was present in $79.74 \%$ \& $87 \%$ respectively. Milk was considered as a good source by $43.98 \%$ of the participants whereas cereals which contain inhibitors for iron absorption was considered as a good source by $18.35 \%$. These findings indicate that their knowledge about good sources of iron was poor (Table 4).

Most of the participants $(42.72 \%)$ received the information regarding anemia and iron rich diet from medical professionals particularly doctors. The role of media in imparting knowledge regarding anemia was found to be poor. At least $1 / 5^{\text {th }}$ of the participants had not received educational information regarding anemia from any source (Table 5).

The overall attitude towards antenatal check-up, healthy diet and the benefits of iron supplementation was generally good among the participants (Table 6).

Table 1: Socio demographic data of participants $(n=316)$.

\begin{tabular}{|lll|}
\hline AGE & $\mathrm{N}=316$ & Percentage \\
\hline$<20$ & 9 & 2.8 \\
\hline $20-29$ & 276 & 87.3 \\
\hline 30 \& above & 31 & 9.8 \\
\hline Parity & & \\
\hline Primi & 126 & $39.87 \%$ \\
\hline Multi & 190 & 60.12 \\
\hline Education & & \\
\hline Illiterate & 16 & 5.06 \\
\hline School & 200 & 63.29 \\
\hline College & 100 & 31.64 \\
\hline Gestational age & & \\
\hline $1-3$ months & 30 & 9.49 \\
\hline 4-6 & 103 & 32.59 \\
\hline $7-9$ & 183 & 57.91 \\
\hline Occupation & & \\
\hline Working & 37 & 11.7 \\
\hline Homemaker & 279 & 88.2 \\
\hline Income & & \\
\hline$>10,000$ & 90 & 24.8 \\
\hline $5000-10000$ & 137 & 43.35 \\
\hline$<5000$ & 89 & 28.16 \\
\hline Toilet facility & & 76.26 \\
\hline Yes & 241 & 23.73 \\
\hline No & 75 & \\
\hline
\end{tabular}

Table 2: Knowledge of the participants regarding anemia, iron rich foods and iron supplements.

\begin{tabular}{|c|c|c|c|}
\hline Responses & $\begin{array}{l}\text { Correct } \\
\text { Response }\end{array}$ & $\begin{array}{l}\text { Wrong } \\
\text { Response }\end{array}$ & $\begin{array}{l}\text { Don't } \\
\text { know }\end{array}$ \\
\hline $\begin{array}{l}\text { Knowledge } \\
\text { regarding what is } \\
\text { anemia }\end{array}$ & $\begin{array}{l}126 \\
(39.87)\end{array}$ & $\begin{array}{l}72 \\
(22.8)\end{array}$ & $\begin{array}{l}118 \\
(37.3)\end{array}$ \\
\hline $\begin{array}{l}\text { Anemia is more } \\
\text { prevalent in } \\
\text { pregnant women }\end{array}$ & $\begin{array}{l}170 \\
(53.8)\end{array}$ & $\begin{array}{l}26 \\
(8.2)\end{array}$ & $\begin{array}{l}120 \\
(37.9)\end{array}$ \\
\hline $\begin{array}{l}\text { Pregnant women } \\
\text { can develop } \\
\text { complications due } \\
\text { to anemia }\end{array}$ & $\begin{array}{l}208 \\
(65.8)\end{array}$ & $\begin{array}{l}24 \\
(7.6)\end{array}$ & $\begin{array}{l}84 \\
(26.58)\end{array}$ \\
\hline $\begin{array}{l}\text { Severe anemia can } \\
\text { affect growth of } \\
\text { the fetus }\end{array}$ & $\begin{array}{l}209 \\
(66.1)\end{array}$ & $\begin{array}{l}17 \\
(5.37)\end{array}$ & $\begin{array}{l}90 \\
(24.48)\end{array}$ \\
\hline $\begin{array}{l}\text { Pregnant women } \\
\text { should take iron } \\
\text { supplementation in } \\
\text { spite of taking } \\
\text { healthy diet }\end{array}$ & $\begin{array}{l}103 \\
(32.6)\end{array}$ & $\begin{array}{l}141 \\
(44.62)\end{array}$ & $\begin{array}{l}72 \\
(22.8)\end{array}$ \\
\hline $\begin{array}{l}\text { Excessive } \\
\text { consumption of } \\
\text { Tea/coffee can lead } \\
\text { to IDA }\end{array}$ & $\begin{array}{l}105 \\
(33.2)\end{array}$ & $\begin{array}{l}72 \\
(22.8)\end{array}$ & $\begin{array}{l}139 \\
(43.98)\end{array}$ \\
\hline $\begin{array}{l}\text { Consuming Iron } \\
\text { along with food } \\
\text { reduces side } \\
\text { effects. }\end{array}$ & $\begin{array}{l}133 \\
(42.08)\end{array}$ & $\begin{array}{l}65 \\
(20.6)\end{array}$ & $\begin{array}{l}118 \\
(37.3)\end{array}$ \\
\hline $\begin{array}{l}\text { Iron tablets are } \\
\text { dispensed free of } \\
\text { cost in Government } \\
\text { hospitals }\end{array}$ & $\begin{array}{l}271 \\
(85.75)\end{array}$ & $9(2.84)$ & $\begin{array}{l}36 \\
(11.39)\end{array}$ \\
\hline $\begin{array}{l}\text { Awareness of } \mathrm{Hb} \\
\text { level during } \\
\text { pregnancy }\end{array}$ & $\begin{array}{l}\text { Yes 141 } \\
(44.62)\end{array}$ & $\begin{array}{l}\text { No } 175 \\
(55.37)\end{array}$ & \\
\hline
\end{tabular}

Table 3: Reasons perceived by antenatal women for cause of anemia.

\begin{tabular}{|lll|}
\hline Reasons & No. of cases & Percentage \\
\hline $\begin{array}{l}\text { Not consuming Iron } \\
\text { rich diet }\end{array}$ & 259 & (81.96) \\
\hline $\begin{array}{l}\text { Not taking Iron } \\
\text { supplementation during } \\
\text { pregnancy }\end{array}$ & 163 & (51.58) \\
\hline $\begin{array}{l}\text { No interval between } \\
\text { subsequent pregnancies }\end{array}$ & 112 & (35.44) \\
\hline $\begin{array}{l}\text { Increased blood loss } \\
\text { during periods }\end{array}$ & 99 & (31.32) \\
\hline $\begin{array}{l}\text { Due to hook worm } \\
\text { infestation }\end{array}$ & 73 & (23.1) \\
\hline
\end{tabular}


Table 4: Knowledge regarding food rich in iron.

\begin{tabular}{|lll|}
\hline Food rich in iron & No. of cases & Percentage \\
\hline Dates/dry fruits & 205 & 64.87 \\
\hline Chicken/Mutton & 82 & 25.94 \\
\hline Green leafy vegetables & 252 & 79.74 \\
\hline Eggs & 130 & 41.13 \\
\hline Milk & 139 & 43.98 \\
\hline Cereals & 58 & 18.35 \\
\hline
\end{tabular}

Table 5: Information regarding anemia.

\begin{tabular}{|lll|}
\hline Source & No. of cases & Percentage \\
\hline T.V & 33 & 10.44 \\
\hline Radio & 1 & 0.3 \\
\hline Hospital & 51 & 16.13 \\
\hline Nurses / Health workers & 37 & 11.7 \\
\hline Doctors & 135 & 42.72 \\
\hline None & 64 & 20.25 \\
\hline
\end{tabular}

Table 6: Attitude of the participants regarding antenatal check-up, iron rich diet and iron supplementation.

\begin{tabular}{|c|c|c|c|}
\hline Responses & Agree & NA or DA & Disagree \\
\hline $\begin{array}{l}\text { Regular } \\
\text { antenatal check- } \\
\text { up and blood } \\
\text { tests are } \\
\text { essential during } \\
\text { pregnancy }\end{array}$ & $\begin{array}{l}265 \\
(83.86)\end{array}$ & $\begin{array}{l}42 \\
(13.30)\end{array}$ & $9(2.84)$ \\
\hline $\begin{array}{l}\text { It is essential to } \\
\text { take special diet } \\
\text { during } \\
\text { pregnancy }\end{array}$ & $\begin{array}{l}239 \\
(75.63)\end{array}$ & $\begin{array}{l}54 \\
(17.08)\end{array}$ & $23(7.27)$ \\
\hline $\begin{array}{l}\text { Mother and } \\
\text { baby are } \\
\text { benefitted by } \\
\text { taking Iron } \\
\text { tablets }\end{array}$ & $\begin{array}{l}281 \\
(88.92)\end{array}$ & $\begin{array}{l}33 \\
(10.44)\end{array}$ & 20.63 \\
\hline $\begin{array}{l}\text { Pregnant } \\
\text { women should } \\
\text { consume Iron } \\
\text { tablets inspite of } \\
\text { healthy diet }\end{array}$ & $\begin{array}{l}213 \\
(67.4)\end{array}$ & $\begin{array}{l}72 \\
(22.78)\end{array}$ & $31(9.8)$ \\
\hline $\begin{array}{l}\text { Promotion of } \\
\text { family planning } \\
\text { methods for } \\
\text { spacing with } \\
\text { prevent anemia }\end{array}$ & $\begin{array}{l}182 \\
(57.59)\end{array}$ & $119(37.65)$ & $15(4.74)$ \\
\hline
\end{tabular}

Regarding practice, $49.36 \%$ of the participants were taking only the usual diet during their pregnancy. $74.36 \%$ claimed to have taken iron supplementation regularly whereas $9.8 \%$ had not taken iron supplementation. Most of the participants consumed iron tablets after food intake and $51.9 \%$ of them said that forgetfulness was the reason for not taking iron supplementation regularly (Table 7).

The mean knowledge and attitude score of the participants was found to be $4.73 \pm 2.35$ (maximum score 9) and $13.47 \pm 1.62$ (maximum score 15). On hemoglobin estimation it was found that $62.97 \%$ of the participants were anemic taking $11 \mathrm{gm}$ as the cut off for anemia. The percentage of participants with good knowledge was $52.53 \%$ i.e. above the mean score and $59.49 \%$ had a positive attitude towards antenatal checkup and iron supplementation during pregnancy.

On studying the possible determinants of anemia using Chi square test, it was found that none of the socio demographic factors were significant predictors of hemoglobin status of the pregnant women. It was also found that factors like receiving counselling regarding anemia and knowledge or attitude scores of the participants did not determine their hemoglobin levels. The only significant determinants of hemoglobin levels were regular intake of iron supplements ( $p$ value 0.006 ) and timing of iron consumption ( $\mathrm{p}$ value 0.0262) (Table 8).

Table 7: Practices of participants.

\begin{tabular}{|c|c|c|}
\hline Practices & No. of cases & Percentage \\
\hline \multicolumn{3}{|c|}{ How is your food habit after becoming pregnant? } \\
\hline $\begin{array}{l}\text { Taking the usual } \\
\text { diet }\end{array}$ & 156 & 49.36 \\
\hline $\begin{array}{l}\text { Taking the } \\
\text { special diet }\end{array}$ & 160 & 50.63 \\
\hline \multicolumn{3}{|c|}{ Are you taking iron tablets during this pregnancy } \\
\hline Regular & 235 & 74.36 \\
\hline Irregular & 50 & 15.82 \\
\hline Not taking & 31 & 9.81 \\
\hline \multicolumn{3}{|c|}{ When are you taking Iron tablets? } \\
\hline Before food & 32 & 10.12 \\
\hline After food & 246 & 77.84 \\
\hline With food & 7 & 2.21 \\
\hline \multicolumn{3}{|c|}{ What is the reason for irregular iron consumption? } \\
\hline Forgetfulness & 164 & 51.9 \\
\hline Side effects & 58 & 18.35 \\
\hline It is not & 44 & 13.92 \\
\hline necessary & 34 & 10.75 \\
\hline Cost & 17 & 5.37 \\
\hline Not prescribed & & \\
\hline
\end{tabular}


Table 8: Determinants of anemia.

\begin{tabular}{|c|c|c|c|}
\hline Determinant of Anemia & $\begin{array}{c}\text { Not Anemic } \\
\text { No. of cases ( } \%)\end{array}$ & $\begin{array}{l}\text { Anemic } \\
\text { No. of cases }(\%)\end{array}$ & $\begin{array}{l}\text { Chi square, d.f, } \\
\text { p-value }\end{array}$ \\
\hline \multicolumn{4}{|l|}{ Parity } \\
\hline Primi & $52(40.9)$ & $75(59.1)$ & \multirow{2}{*}{$\begin{array}{c}1.178,1 \\
0.2790\end{array}$} \\
\hline Multi & $66(34.9)$ & $123(65.1)$ & \\
\hline \multicolumn{4}{|l|}{ Education } \\
\hline Illiterate & $4(26.7)$ & $11(73.3)$ & \multirow{3}{*}{$\begin{array}{c}5.206,2 \\
0.0741\end{array}$} \\
\hline School & $67(33.7)$ & $132(66.3)$ & \\
\hline College & $47(46.1)$ & $55(53.9)$ & \\
\hline \multicolumn{4}{|l|}{ Gestational age } \\
\hline 1 to 3 months & $10(33.3)$ & $20(66.7)$ & \multirow{3}{*}{$\begin{array}{c}1.9176,2, \\
0.3834\end{array}$} \\
\hline 4 to 6 months & $44(42.7)$ & $59(57.3)$ & \\
\hline 7 to 9 months & $64(35.0)$ & $119(65.0)$ & \\
\hline \multicolumn{4}{|l|}{ Income } \\
\hline$>10000$ & $35(38.5)$ & $56(61.5)$ & \multirow{3}{*}{$\begin{array}{c}2.1463,2 \\
0.3419\end{array}$} \\
\hline 5000 to 10000 & $56(40.6)$ & $82(59.4)$ & \\
\hline$<5000$ & $27(31.0)$ & $60(69.0)$ & \\
\hline \multicolumn{4}{|l|}{ H/O Anemia } \\
\hline Yes & $12(37.5)$ & $20(62.5)$ & \multirow{3}{*}{$\begin{array}{l}0.1104,2, \\
0.9463\end{array}$} \\
\hline No & $61(36.5)$ & $106(63.5)$ & \\
\hline Not applicable & $45(38.5)$ & $72(61.5)$ & \\
\hline \multicolumn{4}{|l|}{ Counselling done } \\
\hline Yes & $35(37.6)$ & $58(62.4)$ & \multirow{2}{*}{$\begin{array}{c}0.0017,1, \\
0.9670\end{array}$} \\
\hline No & $83(37.4)$ & $139(62.6)$ & \\
\hline \multicolumn{4}{|l|}{ KS 1} \\
\hline Above mean & $61(36.7)$ & $105(63.3)$ & \multirow{2}{*}{$\begin{array}{c}0.0529,1 \\
0.8181\end{array}$} \\
\hline Below mean & $57(38.0)$ & $93(62.0)$ & \\
\hline \multicolumn{4}{|l|}{ AS 2} \\
\hline Above mean & $76(40.4)$ & $112(59.6)$ & \multirow{2}{*}{$\begin{array}{c}2.152,1 \\
0.1425\end{array}$} \\
\hline Below mean & $41(32.3)$ & $86(67.7)$ & \\
\hline \multicolumn{4}{|l|}{ Iron consumption } \\
\hline Regular & $99(42.3)$ & $135(57.70$ & \multirow{3}{*}{$\begin{array}{c}10.2361,2, \\
0.006\end{array}$} \\
\hline Irregular & $10(19.6)$ & $41(80.4)$ & \\
\hline Not taking & $9(29.0)$ & $22(71.0)$ & \\
\hline \multicolumn{4}{|l|}{ Diet } \\
\hline Usual & $52(34.4)$ & $99(65.6)$ & \multirow{2}{*}{$\begin{array}{l}1.043,1 \\
0.309\end{array}$} \\
\hline Special & $66(40.0)$ & $99(60.0)$ & \\
\hline \multicolumn{4}{|l|}{ Timing } \\
\hline $\mathrm{BF}$ & $7(21.9)$ & $25(78.1)$ & \multirow{3}{*}{$\begin{array}{c}7.2819,2, \\
0.0262\end{array}$} \\
\hline $\mathrm{AF}$ & $107(38.4)$ & $172(61.6)$ & \\
\hline WF & $4(80.0)$ & $1(20.0)$ & \\
\hline \multicolumn{4}{|l|}{ Toilet } \\
\hline Yes & $95(39.4)$ & $146(60.6)$ & \multirow{2}{*}{$\begin{array}{c}1.873,1 \\
0.1713\end{array}$} \\
\hline No & $23(30.7)$ & $52(69.3)$ & \\
\hline
\end{tabular}

\section{DISCUSSION}

The present study showed that overall $52.5 \%$ of the participants had good knowledge regarding anemia, Iron rich food and iron supplementation but when specifically questioned only $39.87 \%$ were aware of and understood the term anemia. A similar study from Karnataka also showed that knowledge regarding anemia and healthy diet was poor among pregnant women. ${ }^{3}$ Other studies have also indicated that nutritional knowledge was remarkably low in pregnant women. ${ }^{4}$ A study comparing nutritional awareness between urban and rural mothers showed that rural mothers were not aware of the consequences of inadequate nutrition during pregnancy ${ }^{5}$. In the present study which was in a rural setting awareness of the consequences of anemia to the mother 
and baby and attitude towards healthy diet and iron supplementation was fairly good.

A study by Ayesha et al from Pakistan showed that even though $66 \%$ of pregnant women were aware of anemia only $21 \%$ of their participants attributed lack of iron rich diet to be the cause of anemia. ${ }^{6}$ This study also found that the overall knowledge regarding iron rich foods was poor among their participants. In our study, $81.96 \%$ were aware that consumption of diet poor in iron to be the reason behind anemia but knowledge about iron rich foods was lacking among our participants. $79.74 \%$ had rightly said that green leafy vegetables are a good source of iron but only $25.9 \%$ considered meat as a good source of iron. Awareness regarding hook worm infestation as a cause of anemia was present only $23.1 \%$ of our participants. This is significant as $23.7 \%$ of the participants lacked toilet facilities and de-worming is not practiced routinely. Only $3.8 \%$ of women reported to have taken de -worming drugs in NFHS3 survey. ${ }^{1}$

Many studies indicated that factors like education, age at marriage, socioeconomic status, poor knowledge, lack of births spacing and history of anemia before pregnancy were significant determinants of anemia., ${ }^{7,8}$ Another study on influence of awareness and attitude about anemia in South India found that, in women in rural areas misconceptions regarding oral iron intake and lack of counselling by health workers were significant predictors of anemia. ${ }^{9}$ But in the present study no such association was found. Practice of regular of intake of iron and folic acid and timing of iron consumption were the two independent variables that were significantly associated with the hemoglobin levels of pregnant women in the present study.

A similar association between regular intake and hemoglobin levels was also found in a study on compliance of iron and folic acid therapy. This study showed that significant fall in hemoglobin was observed when less than 50 tablets were consumed as compared to a maximum rise when more than 125 tablets were consumed by pregnant women. ${ }^{10}$ NFHS 3 survey reports that only $23.1 \%$ of pregnant women consumed iron and folic acid for 90 days. ${ }^{1}$ A study from rural Bihar also reported a similar finding of $24 \%$ whereas in our study $74.86 \%$ claimed to have taken iron and folic acid regularly. ${ }^{11}$ Studies indicate that women were likely to take iron and folic acid regularly if they received additional nutritional counselling during pregnancy. ${ }^{11}$

The emphasis is mainly on nutritional counselling during pregnancy as indicated by a study in slums of Delhi, that even though pregnant women had regular antenatal visits, nutritional counselling to them was lacking. ${ }^{12}$ They reported an anemia prevalence of $85 \%$ in their study inspite of good antenatal care. Our study also showed that almost $70 \%$ of the participants have not received adequate counselling regarding anemia and the anemia incidence was $62.9 \%$.

\section{CONCLUSIONS}

The present study indicated the lack of knowledge regarding anemia, iron rich foods and the importance of iron supplementation during pregnancy. As awareness motivates behavioural changes, awareness should be created through appropriate nutritional counselling during antenatal visits and through media .Effective measures to provide toilet facilities to all rural households by the government to be considered. De-worming should be intensively practiced in all pregnant women. Targeted estimation of hemoglobin levels in adolescent girls and women in reproductive age group, intensive counselling and motivation of pregnant women to consume Iron and folic acid and ensuring adequate supply to them would help in reducing the incidence of anemia in pregnant women.

\section{Funding: No funding sources}

Conflict of interest: None declared

Ethical approval: The study was approved by the Institutional Ethics Committee

\section{REFERENCES}

1. National Family Health Survey (NFHS - III) 2005, 2006.

2. India's undernourished children: a call for report and action, World bank report.

3. Yadav RK, Swamy MK, Banjade B. Knowledge and practice of anemia among pregnant women attending antenatal clinic in Dr. Prabhakar Kore hospital, Karnataka-A cross sectional study. IOSR Journal of Dental and Medical Sciences. 2014;13(4):74-80.

4. Kelsey B. The perception of maternal anemia and the effect of Nutritional education: A qualitative analysis among village mothers in rural Kumaon, Uttarkhand (2013). Independent study project (ISP) collection paper 1705 .

5. Payghan BS, Swapna SK, Mayuri R. A comparative study of Nutritional awareness among urban Rural pregnant mothers, Research and reviews. Journal of Medical and Health sciences. 2014;3(4):95-9.

6. Mohammad A, Rizvi. F, Irfan G. Impact of maternal education and socioeconomic status on maternal nutritional knowledge and practices regarding iron rich foods and iron supplements. Ann Pak Inst Med. Sci. 2012;8:101-5

7. Maskey M, Jha N, Poudel SI, Yadav D. Anemia in pregnancy and its associated factors: A study from Eastern Nepal. Nepal Journal of Epidemiology. 2014;4(4):386-92.

8. Abdelnefez AM, EI-Soadaa SS. Prevalence and risk factors of anemia among a sample of pregnant females attending primary health care .Pak J Nutr. 2012;11:1113-20.

9. Dorairajan G, Palanivel C, Sakthi D. Influence of awareness and attitude about anemia and iron 
supplements on prediction of anemia among pregnant women. BJOG. 2014;121:153-76.

10. Gautam VP, Bansal Y, Taneja DK, Ingle GK. A study on compliance to iron-folic acid therapy and its effects on anemia during pregnancy. Indian $\mathrm{J}$ Prev soc Med. 2005;36(3-4):102-7.

11. Wendt A, Stephenson R, Young M, Webb-Girard A, Hogue C, Ramakrishnan U(2015). Individual and facility level determinants of iron and folic acidreceipt and adequate consumption among women in rural Bihar, India. PLOS One. 2015;10(3):e0120404.

12. Ghosh-Jerath S, Devasenapathy N, Singh A, Shankar A, Zodpey S. Antenatal care utilization, dietary practices and nutritional outcomes in pregnant and recently delivered women in urban slums of Delhi, India: Anexploratory cross sectional study. Reprod Health. 2015;12(1):20.

Cite this article as: Nivedita K, Shanthini FN. Knowledge, attitude and practices of pregnant women regarding anemia, iron rich diet and iron supplements and its impact on their hemoglobin levels. Int J Reprod Contracept Obstet Gynecol 2016:5:425-31. 